Publisher homepage: www.universepg.com, ISSN: 2707-4668 (Online) \& 2707-465X (Print) https://doi.org/10.34104/ajssls.020.047055

Asian Journal of Social Sciences and Legal Studies Journal homepage: www.universepg.com/journal/ajssls

\title{
Analysis of Cyclone Shelter Patterns to Build a Better Shelter Management: A Case Study of Bangladesh Southern Region
}

\author{
Md. Rasheduzzaman ${ }^{1 *}$, Azim Uddin ${ }^{2}$, Md. Shamsuzzoha ${ }^{3}$, and Muhammad Arifur Rahman ${ }^{4}$ \\ ${ }^{1-3}$ Department of Emergency Management, Patuakhali Science and Technology University, Dumki, Patuakhali-8602, \\ Bangladesh; and ${ }^{4}$ Department of Environmental Science, Patuakhali Science and Technology University, Dumki, Patuakhali- \\ 8602, Bangladesh. \\ *Correspondence: rashederm@pstu.ac.bd (Md. Rasheduzzaman, Lecturer, Department of Emergency Management, \\ Patuakhali Science and Technology University, Bangladesh)
}

\begin{abstract}
Bangladesh is located geographically in a vulnerable location. Every year different types of natural disasters like cyclone, flood, Nor'wester, tornado, storm surge, salinity, drought, river erosion, river bed siltation, land slide, etc. visit in our country. Cyclone is a very common phenomenon in our country. Cyclone shelter is the haven place for the coastal people during the cyclonic event. There are various types of cyclone shelters in the coastal areas of Bangladesh. The overall aim of the research is to identify the best types of cyclone shelters for better shelter management. A total of ten types of cyclone shelters are considered to conduct this research work. The qualitative and quantitative data were analyzed. A priority index matrix is made to identify the best types of cyclone shelters. Different types of data were analyzed viz. access road conditions, enter and exit facilities, physical elements of the cyclone shelters. From the data analysis, it is identified that type 6 cyclone shelter is the best pattern among ten cyclone shelters. This research finds out some weaknesses of the current shelter management practices like a warning signal, poor condition of the shelter, relief work-related problem, electricity, drinking water and limited logistic support. Finally, the research also made some recommendations for new builds, existing, and institutional arrangements of cyclone shelters that may help to improve the future establishment of cyclone shelters in coastal areas of Bangladesh. So, the identified better pattern of cyclone shelter will improve the emergency management system by providing better shelter management facilities during emergency situation of any cyclonic event.
\end{abstract}

Keywords: Cyclone shelter, Analysis, Shelter management, Bangladesh south region, and Management.

\section{INTRODUCTION}

Bangladesh is the most disaster-prone countries in the world (Ali, 1996). The geographical location, the geological setting of the country and tropical monsoon climate modify and regulate the climatic conditions and make the country more vulnerable to natural disasters (As-Salek, 1998). Almost every year different types of natural calamities occur in Bangladesh and destroy many lives and resources of people (Wisner et al., 2014). Disasters such as floods, river bank erosion, cyclone, tornado, water logging, salinity intrusion, etc. are gradually increasing day by day and composing risks for the coastal people in Bangladesh (Nasreen et al., 2013). 
The concept of building cyclone shelter in the coastal belt of Bangladesh originated in the early sixties. After the devastating cyclone of 1960-61 the Government of Bangladesh decided to build a number of two story buildings in the coastal areas, the upper floor of which could be used as shelter at the time of cyclones (Choudhury, 1994). In the 1990s a major program was undertaken and cyclone shelters were built in the coastal areas. Multipurpose cyclone shelters were built mainly after the cyclone of 1991 (Ahamed, 2011). These cyclone shelters provide shelter to the coastal community and help a lot to reduce the number of casualty in the coastal areas during cyclone. Normally people of the surrounding area took shelter in the cyclone shelters. As a part of preparedness for disasters, people should be evacuated to the shelters/safe locations as early as possible. If people know where they should go during disaster, they could move faster to the shelters that can reduce mortality rate (CEGIS, 2009). Standard shelters are designed to provide basic services to support a normal life by ensuring the security, privacy, and dignity of the affected people (Bagchi et al., 2019; and Uddin et al., 2018).

The frequency of severe cyclone and storm surges is such that the shelters are likely to be used only once in four to five years. Since the shelter building are quite expensive structure, it would not be economically justifiable unless some normal time use can be ensured (Choudhury, 1994). The normal time uses of cyclone shelter may include educational institutions (Primary school, Secondary school, Dakhil madrasah, Vocational training institutions, and colleges), health and family welfare center, community centers, offices, mosque etc. The main objective of the research is to identify the best types of cyclone shelters to build a better shelter management. The following two specific objectives are being developed to complete the study; first one is to identify the existing patterns of cyclone shelters and the second one is to find out the best cyclone shelter pattern to improve better shelter management in the study area.

\section{Study Area}

Kalapara upazila of Patuakhali district was selected as the study area for conducting this research work. This is one of the worst affected upazila by cyclone and storm surge and many other climatic hazards. There are many cyclone shelters have been constructed in this region. Kalapara upazila has thirteen unions (BBS, 2012). Because of limitation of time and other facilities, two unions of them named Nilganj and Tiakhali were selected for the study (Fig 1).
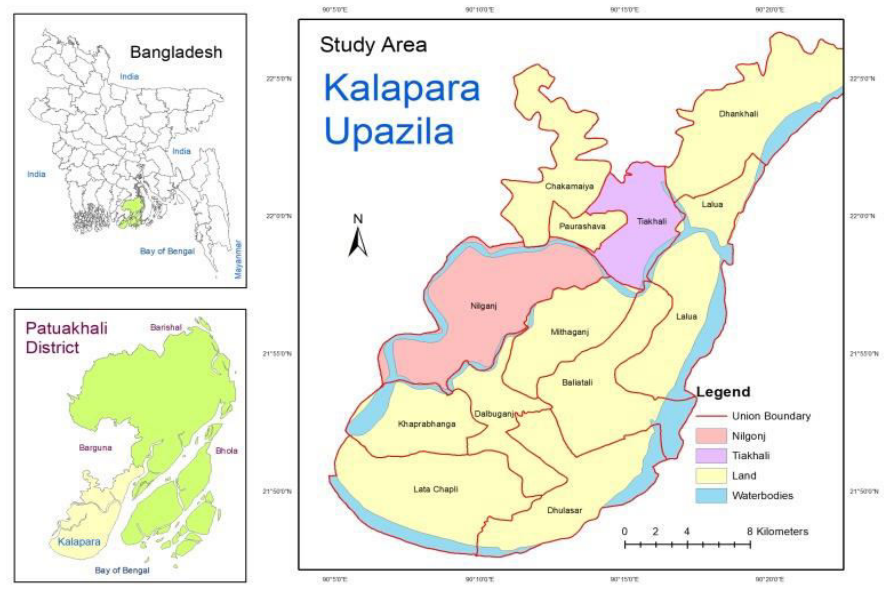

Fig 1: Study Area Map.

\section{MATERIALS AND METHODS}

2.1 Sources of Data Collection - The study was done with the close accordance of the objectives. Quantitative and qualitative data were used to complete the study. Questionnaire survey method was used to collect primary data from respondents of the study area. Lots of interesting and important findings came out in the discussion that was very helpful to complete my research.

The data for this study was collected both from primary and secondary sources. Primary data was collected through the direct observation, questionnaire survey; transect walk and focus group discussion. Firstly, the persons near the cyclone shelters of designated unions who are generally go to the cyclone shelters during cyclone were selected. From them, we have taken randomly interviewed with fifty persons in each of Nilganj and Tiakhali union. The selected households are farmer, fishermen, small trader, government employee etc. The secondary data had been collected from different relevant articles, reports, maps, journals, research paper, website, library, Kalapara upazila Project Implementation Office (PIO), reports from local NGO offices etc. 
2.2 Data Analysis - Different tables, diagrams and charts have used for processing the relevant collected data. Collected data were analyzed through the Microsoft Excel 2010 to make graphical diagrams and the report was written on the Microsoft Word 2010. An index matrix is used for ranking the best types of cyclone shelter in the study area.

\section{RESULTS AND DISCUSSION}

\subsection{Structure of Different Types Cyclone Shelter}

Table 1: Summary of Structural Components and Elements of Different Types Cyclone Shelters.

\begin{tabular}{|c|c|c|c|c|c|c|c|}
\hline 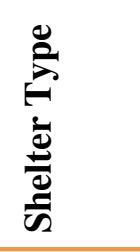 & 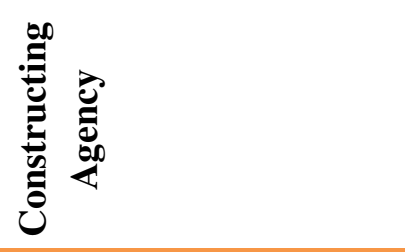 & $\stackrel{0.00}{:}$ & 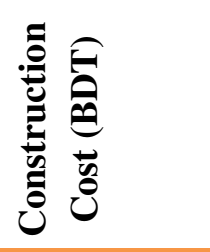 & 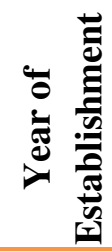 & 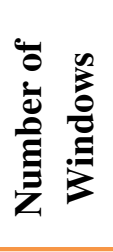 & 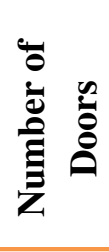 & 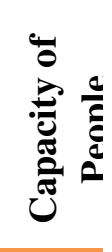 \\
\hline Type 1 & BDRCS/Caritas & CAFOD (ODA) & $10,00,000$ & 1993 & 12 & 2 & 650 \\
\hline Type 2 & LGED & $\begin{array}{l}\text { Cabinet Division of } \\
\text { Government }\end{array}$ & $82,00,000$ & 2004 & 20 & 4 & 850 \\
\hline Type 3 & LGED & $\begin{array}{l}\text { Primary Education } \\
\text { Development Program } \\
\text { (PEDP)/LGED }\end{array}$ & $80,00,000$ & 2005 & 12 & 4 & 760 \\
\hline Type 4 & LGED & $\begin{array}{l}\text { CATHOLIC CHURCH, } \\
\text { Chittagong Diocese }\end{array}$ & $72,00,000$ & 2009 & 8 & 4 & 680 \\
\hline Type 5 & Bangladesh Army & Standard Bank Ltd. & $20,00,000$ & 2008 & 16 & 2 & 370 \\
\hline Type 6 & $\begin{array}{l}\text { Islamic Development } \\
\text { Bank, Jeddah, Kingdom } \\
\text { of Saudi Arabia }\end{array}$ & $\begin{array}{l}\text { Islamic Development Bank, } \\
\text { Jeddah, Kingdom of Saudi } \\
\text { Arabia }\end{array}$ & $1,75,00,000$ & 2015 & 32 & 10 & 1620 \\
\hline Type 7 & U.S. Pacific Command & U.S. Pacific Command & $73,50,000$ & 2011 & 14 & 4 & 850 \\
\hline Type 8 & $\begin{array}{l}\text { Cabinet of Educational } \\
\text { Engineering Division of } \\
\text { Government }\end{array}$ & $\begin{array}{l}\text { Cabinet of Educational } \\
\text { Engineering Division of } \\
\text { Government }\end{array}$ & $1,20,00,000$ & 2013 & 24 & 8 & 1000 \\
\hline Type 9 & $\begin{array}{l}\text { Educational Engineering } \\
\text { Division of Government }\end{array}$ & $\begin{array}{l}\text { Educational Engineering } \\
\text { Division of Government }\end{array}$ & $51,00,000$ & 2013 & 12 & 4 & 650 \\
\hline Type 10 & LGED & $\begin{array}{l}\text { Cabinet Division of } \\
\text { Government }\end{array}$ & $1,17,00,000$ & 2016 & 20 & 5 & 960 \\
\hline
\end{tabular}

\subsection{Using Patterns of Cyclone Shelters}

Cyclone shelters are constructed for multipurpose use. It was found from field investigation that among the ten (10) cyclone shelters $70 \%$ was used as educational institutions, $10 \%$ as offices, $10 \%$ as community centers, $10 \%$ do not have any normal time use. A
Various types of structure have been constructed by a number of organizations, which are served as cyclone shelter. Based on the primary data collected from the field survey, similar type of structures was grouped according to structural dimensions, construction and funding agencies and year of construction. The shelters were assembled into ten major groups classified as types 1 to 10 . Besides these, there are some other types of shelters as well. A brief description of all ten types of shelters is presented in the following Table 1. 
access road of cyclone shelters, enter and exit facilities, physical elements analysis and capacity analysis of cyclone shelters

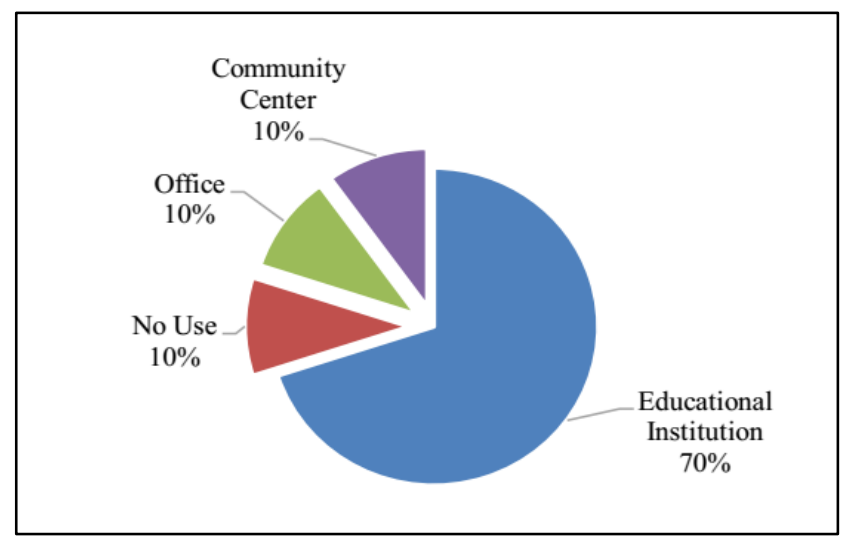

Fig 2: Using Patterns of Cyclone Shelters.

\section{The detail discussion of the data is described in the following section.}

\subsubsection{Road Accessibility of the Cyclone Shelters}

The access roads to the cyclone shelters were divided into four categories like poor, moderate, good and better based on their conditions. There are different types of road for going into the cyclone shelters such as mud, herringbone, concrete and pitch road. Based on the perceptions of the community people, a priority matrix has been made for identifying the best access conditions of cyclone shelters among the ten cyclone shelters. Table 2 identifies the priority matrix of the accessibility of the road conditions of the ten cyclone shelters. For identifying the priority of the best cyclone shelter (1) is used for parameter best, (0.75) is for better, (0.50) is for good, (0.25) is for moderate and (0) is for poor access road conditions. When the respondents were asked about priority wise accessibility of the road condition alone the cyclone shelters, the top priority was given on type 6 cyclone shelter (0.733) for it's access condition. The last priority was given for type 1 cyclone shelter(0.283).

However, type 7 priority rank III, type 10 priority rank IV, type 9 rank V, type 4 rank VI, type 5 rank VII, type 3 rank VIII, type 2 priority rank IX were identified respectively. The priority of accessibility of the road conditions are shown in the below Fig 3. So, the type 6 cyclone shelter has the best access road condition among the ten (10) cyclone shelter.

\subsubsection{Enter and Exit Patterns}

The enter and exit facilities of the cyclone shelters were divided into four categories viz. best, better, good, moderate and poor based on their conditions. There are different types of parameters like stair type, wide of the stair, no. of stairs etc. are analyzed in this matrix index. Based on the respondent's perceptions, a priority matrix has been made for identifying the best enter and exit pattern of cyclone shelters among the ten cyclone shelters.

Table 3 identify the priority matrix of enter and exit pattern of the ten cyclone shelters. For identifying the priority of the best cyclone shelter (1) is used for the parameter best, (0.75) is for better, $(0.50)$ is for good, $(0.25)$ is for moderate and (0) is for poor access road conditions. Fig 4 shows the priority of the enter and exit pattern of the ten cyclone shelters. The top priority was given on type 6 cyclone shelter $(0.750)$ for it's access condition. The last priority was given for type 5 cyclone shelter(0.416). However, for type 3 priority (III), for type 8 priority (IV), for type 2 priority (V), for type 1 priority (VI), for type 9 priority (VII), for type 7 priotiry (VIII), for type 4 priority (IX) were identified. From this paramiter, it is identified that the type 6 cyclone shelter is the best for enter and exit patter of the shelter.

\subsubsection{Physical Elements Analysis}

Cyclone shelter provides the access condition of the affected people through doors. Different types of shelters have different types of doors. The numbers of doors are varied in various cyclone shelters. The figure 5 shows number of doors and windows of these cyclone shelters. The type 1 shelter has 2 doors and 12 windows, type 2 has 4 doors and 20 windows, type 3 has 4 doors and 12 windows, type 4 has 4 doors and 8 windows, type 5 has 2 doors and 16 windows, type 6 has 10 doors and 32 windows, type 7 has 4 doors and 14 windows, type 8 has 8 doors and 24 windows, type 9 has 4 doors and 12 windows and type 10 has 5 doors and 20 windows. 
Table 2: Cyclone Shelter Accessibility Road Condition Index.

Shelter Types

$\begin{array}{lcccccccc}\text { Type } 1 \text { Cyclone Shelter } & 0 & 2 & 9 & 10 & 9 & 30 & 0.283 & \text { X } \\ \text { Type } 2 \text { Cyclone Shelter } & 2 & 3 & 10 & 8 & 7 & 30 & 0.375 & \text { IX } \\ \text { Type } 3 \text { Cyclone Shelter } & 3 & 5 & 6 & 10 & 6 & 30 & 0.408 & \text { VIII } \\ \text { Type } 4 \text { Cyclone Shelter } & 2 & 3 & 13 & 10 & 2 & 30 & 0.441 & \text { VI } \\ \text { Type } 5 \text { Cyclone Shelter } & 2 & 4 & 10 & 10 & 4 & 30 & 0.416 & \text { VII } \\ \text { Type } 6 \text { Cyclone Shelter } & 10 & 12 & 4 & 4 & 0 & 30 & 0.733 & \text { I } \\ \text { Type } 7 \text { Cyclone Shelter } & 7 & 10 & 9 & 4 & 0 & 30 & 0.667 & \text { III } \\ \text { Type } 8 \text { Cyclone Shelter } & 10 & 8 & 7 & 5 & 0 & 30 & 0.691 & \text { II } \\ \text { Type } 9 \text { Cyclone Shelter } & 5 & 5 & 8 & 7 & 5 & 30 & 0.483 & \text { V } \\ \text { Type } 10 \text { Cyclone Shelter } & 9 & 7 & 8 & 6 & 0 & 30 & 0.658 & \text { IV }\end{array}$

Note: (Priority index is calculated for each facility by multiplying each priority with its relative weight given in the parenthesis and dividing by summation of the frequency).

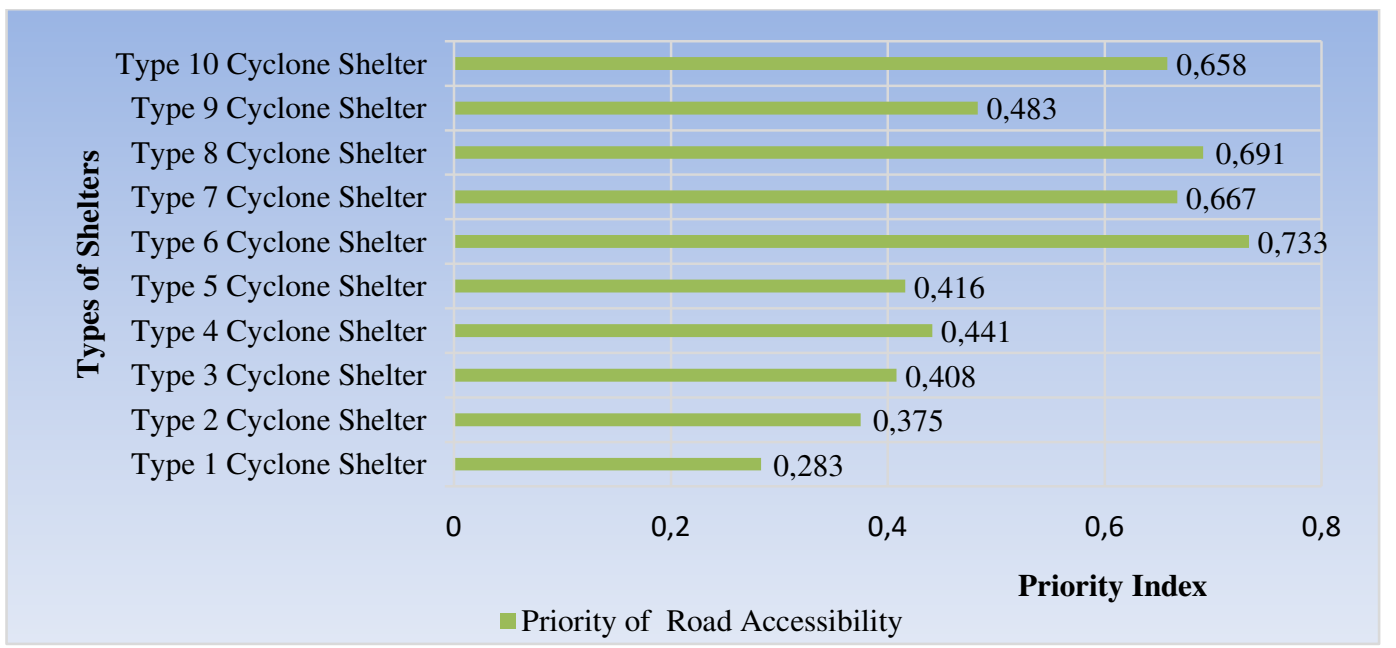

Fig 3: Priority of Access Road Conditions.

After analyzing the data of doors and windows it is identified that type 6 cyclone shelter has the highest number of doors (10) and windows (32). From this physical elements analysis type 6 shelter is the best among the ten types of cyclone shelters.

\subsubsection{Capacity Analysis}

Cyclone shelters provide the safe haven for the cyclone affected people during cyclone. Different cyclone shelters have different capacity due their structural dimensions. Fig 6 shows about the capacity (number of people) of these shelters. Type 1 cyclone shelter has a capacity to contain 650 people, type 2 has a capacity to contain 850 , type 3 has 760 , type 4 has 680 , type 5 has 370, type 6 has 1620, type 7 has 850 , type 8 has 1000 , type 9 has 650 and type 10 has a capacity to contain 960 people. Here type 6 cyclone shelter has the highest capacity to contain 1620 people. So, it is identified that type 6 cyclone shelter is the best among the others. 
Table 3: Cyclone Shelter Enter and Exit Patterns Index.

Shelter Types

Type 1 Cyclone Shelter

Type 2 Cyclone Shelter

Type 3 Cyclone Shelter

Type 4 Cyclone Shelter

Type 5 Cyclone Shelter

Type 6 Cyclone Shelter

Type 7 Cyclone Shelter

Type 8 Cyclone Shelter

Type 9 Cyclone Shelter

Type 10 Cyclone Shelter

Priority of Enter and Exit Pattern Index

\begin{tabular}{cccccccc}
\hline $\begin{array}{c}\text { Best } \\
(\mathbf{1})\end{array}$ & $\begin{array}{c}\text { Better } \\
(\mathbf{0 . 7 5})\end{array}$ & $\begin{array}{c}\text { Good } \\
(\mathbf{0 . 5 0})\end{array}$ & $\begin{array}{c}\text { Moderate } \\
(\mathbf{0 . 2 5})\end{array}$ & $\begin{array}{c}\text { Poor } \\
(\mathbf{0})\end{array}$ & $\begin{array}{c}\text { Total } \\
\text { Frequency }\end{array}$ & $\begin{array}{c}\text { Priority } \\
\text { Index }\end{array}$ & Rank \\
5 & 8 & 7 & 5 & 5 & 30 & 0.525 & VI \\
5 & 10 & 12 & 2 & 1 & 30 & 0.633 & V \\
10 & 8 & 7 & 5 & 0 & 30 & 0.691 & III \\
2 & 5 & 10 & 10 & 3 & 30 & 0.442 & IX \\
2 & 4 & 10 & 10 & 4 & 30 & 0.416 & X \\
12 & 9 & 6 & 3 & 0 & 30 & 0.750 & I \\
2 & 5 & 13 & 6 & 4 & 30 & 0.458 & VIII \\
8 & 10 & 8 & 4 & 0 & 30 & 0.683 & IV \\
5 & 5 & 8 & 8 & 4 & 30 & 0.491 & VII \\
9 & 10 & 7 & 4 & 0 & 30 & 0.700 & II \\
\hline
\end{tabular}

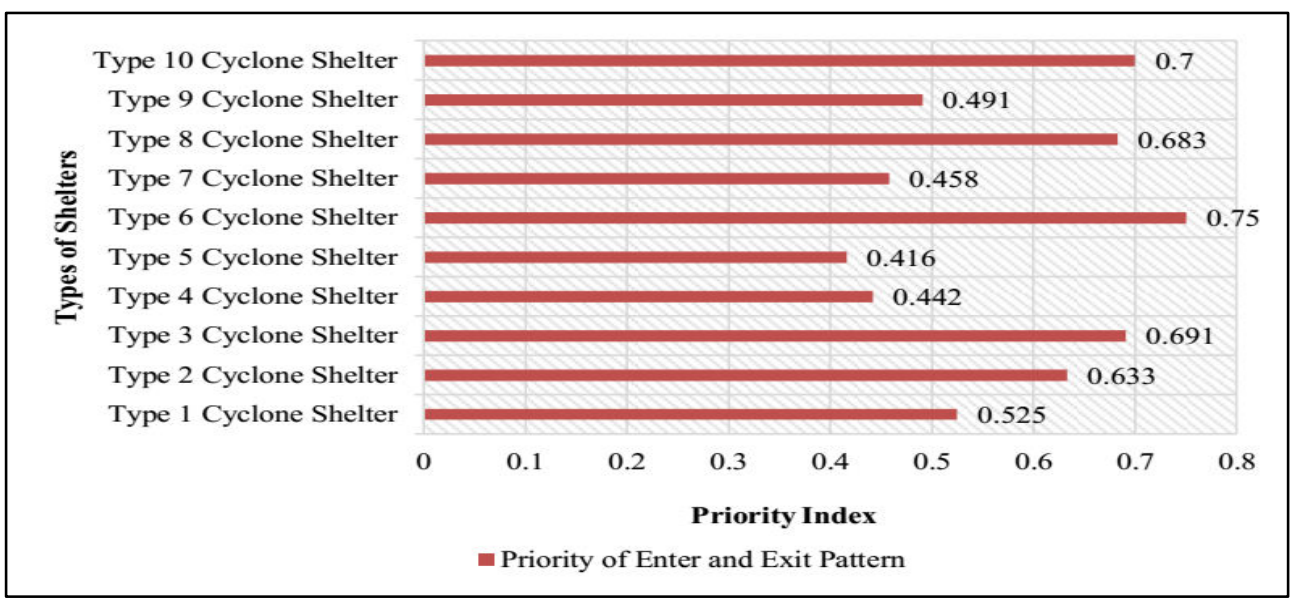

Fig 4: Priority of Enter and Exit Pattern of Cyclone Shelters.

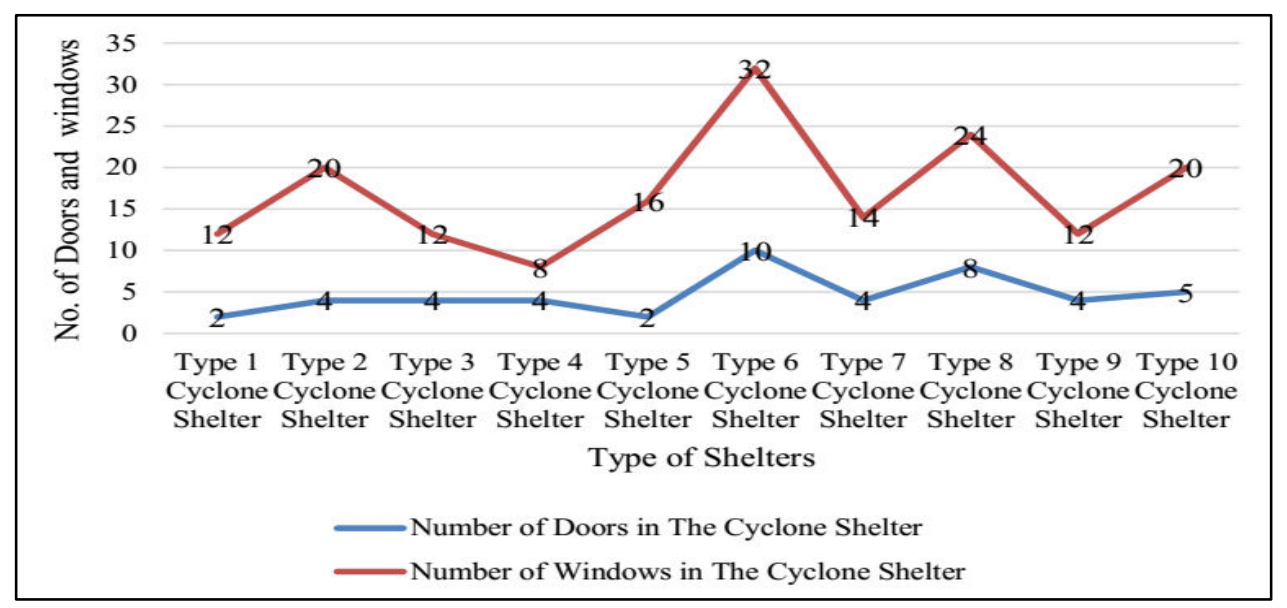

Fig 5: Number of Doors and Windows. 


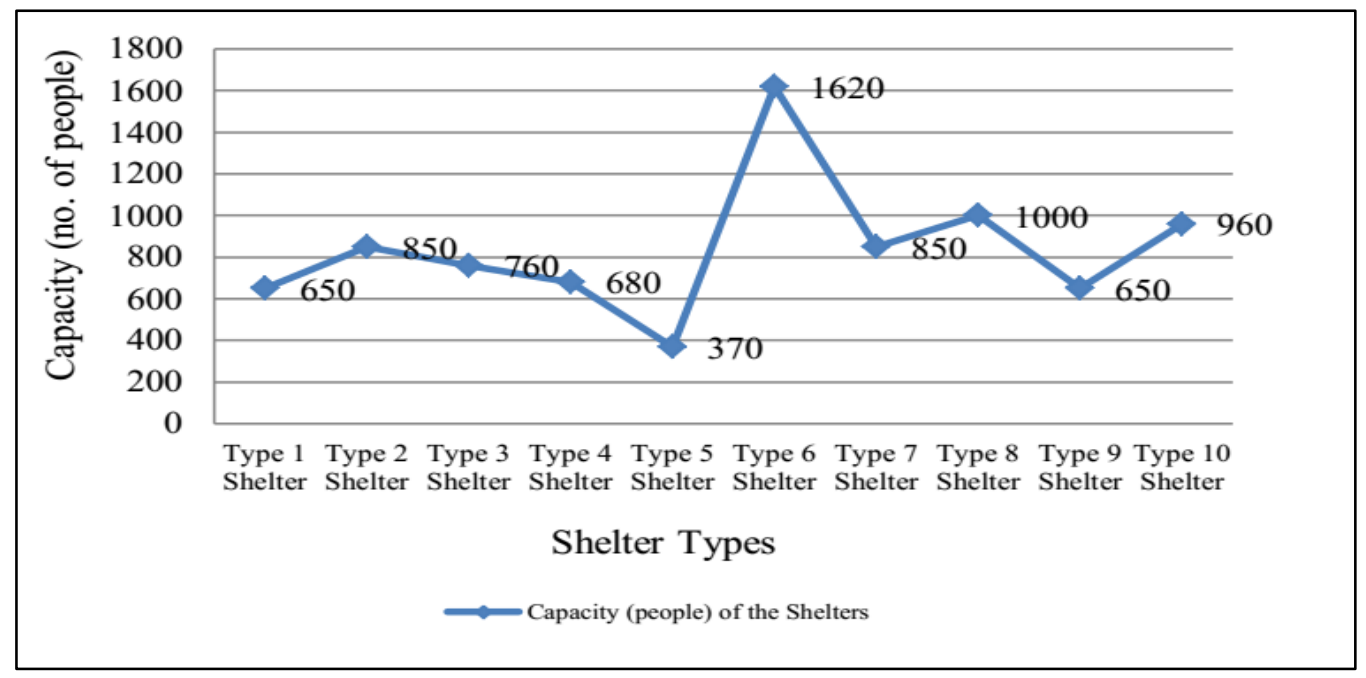

Fig 6: Capacity of Cyclone Shelters.

\subsection{Current Problems of Shelter Management Practices}

The present management of the shelters is primarily looked after the government agencies and the shelter committees developed by the government. From data collection, we have found many problems of shelter management in the study area. Among them the most common problems are presented at the below Fig 7. From the survey, it is observed that most of the respondents $(25 \%)$ have identified major weakness of the unavailability of food, drinking water and medical assistance for cyclone shelter.

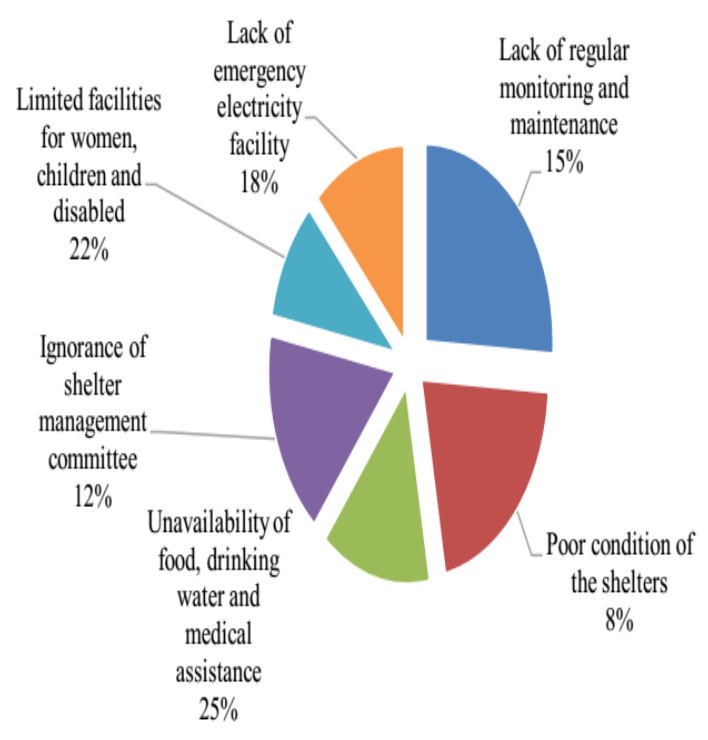

Fig 7: Major weaknesses of Shelter Management in the Study Area.
About 22\% respondents indicate that these shelters have limited facilities for women, children and disabled person. It is important to note that about $18 \%$, $15 \%, 12 \%$ and $8 \%$ respondents respectively have found out lack of emergency electricity facility, Lack of regular monitoring and maintenance of these shelters, ignorance of shelter management committee and poor condition of cyclone shelter as main weaknesses in the existing shelter management system.

\section{CONCLUSION}

This research report is mainly for identifying the best type of cyclone shelter among the ten types of cyclone shelters in the study area. It is identified that type 6 cyclone shelter is the best type of cyclone shelter. The incoming and outgoing system is very important things for any cyclone shelter. The access road conditions along the shelters, enter and exit facilities, analysis of physical elements (doors, windows, no. of stairs and facing conditions) and capacity (people) analysis of cyclone shelters shows that the type 6 cyclone shelter is the best pattern for minimizing impacts of the cyclonic event during emergency period. We have also found out some problems of the existing cyclone shelters in my study area. The problems are like weakness of the existing cyclone warning system, poor condition of cyclone shelter, lack of guidelines for cyclone proof house construction, lack of coastal 
embankments and relief work related problems in the cyclone shelters. We have also found that most of the cyclone shelters have a single stair and it is not enough space for enter and exit during cyclonic emergency situation. Some newly build cyclone shelters have double stair which is very suitable for women, children and disabled person. According to respondent's view, this double stair type cyclone shelter is good enough for incoming and outgoing system during emergency period of the cyclone disaster. At the time of constructing new cyclone shelter in future the spacious and double stair of cyclone shelter should be considered.

\section{APPENDIX}

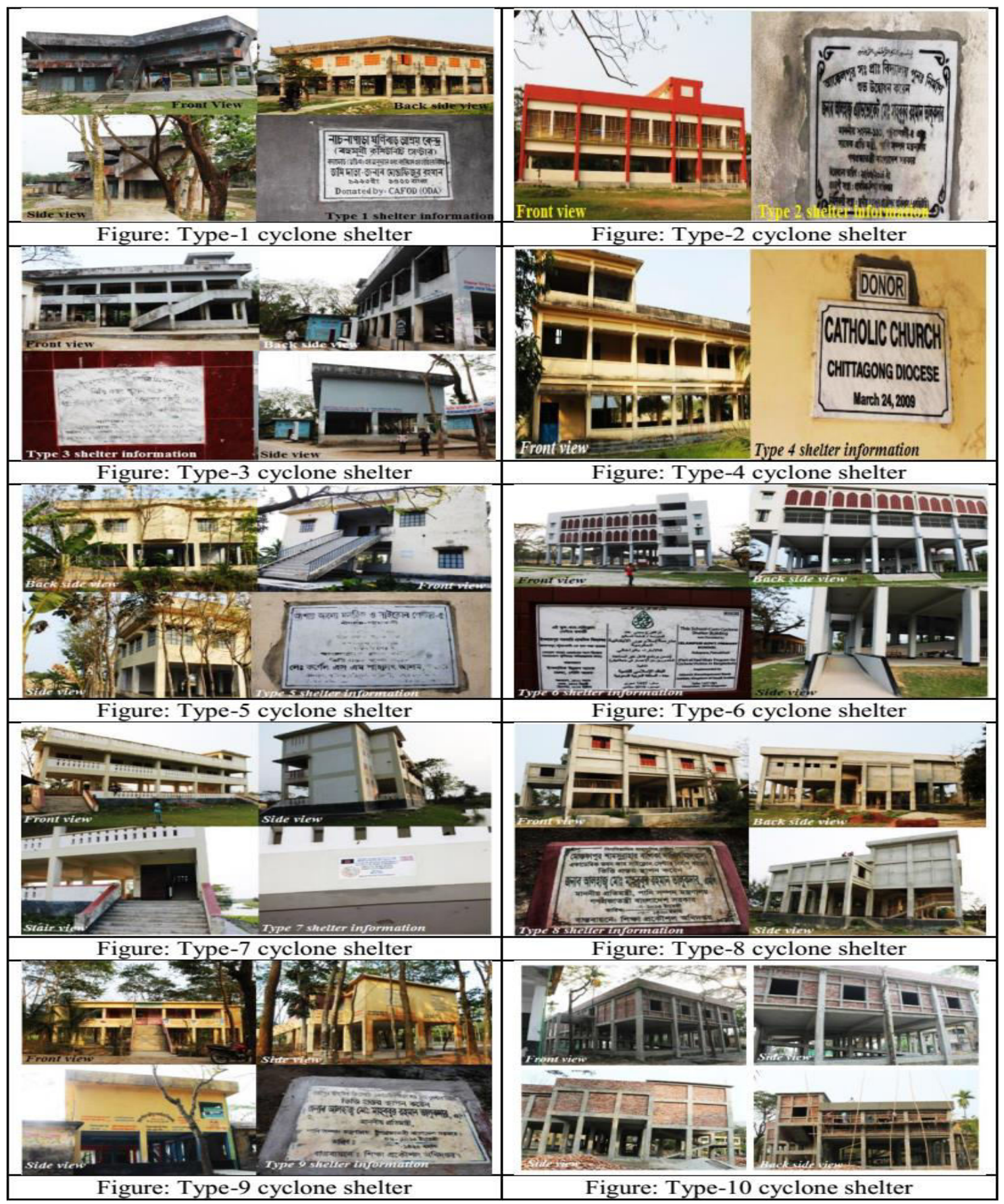

Fig 8: Different types of cyclone shelter in the study area. 


\section{ACKNOWLEDGEMENTS}

Author wishes to thanks and Professor Dr. Md. Shahidul Islam, Director, Institutional Quality Assurance Cell (IQAC), PSTU and Professor Dr. Muhammad Maniruzzaman, Department of Agricultural Chemistry, PSTU, Bangladesh. Most importantly, thanks to all the household members who participated in this study by sharing their knowledge and time to make this research successful.

\section{CONFLICTS OF INTEREST}

The authors declared no possible conflicts of the interest with respect to the research, authorship and publication of this article.

\section{REFERENCES}

1. Ahamed, M. (2011). Assessment for need for additional Cyclone Shelters in some selected Coastal Zone of Bangladesh. Bangladesh University of Engineering and Technology (BUET), 1-153.

http://lib.buet.ac.bd:8080/xmlui/handle/12345 $\underline{6789 / 139}$

2. Ali, A. (1996). Vulnerability of Bangladesh to climate change and sea level rise through tropical cyclones and storm surges. Water, Air, and SoU Pollution 92: 171-179.

3. As-Salek, J. A. (1998). Coastal trapping and funneling effects on storm surges in the Meghna estuary in relation to cyclones hitting Noakhali-Cox's Bazar coast of Bangladesh. Journal of physical oceanography, 28(2), 227249.

https://doi.org/10.1175/1520-0485(1998)

028\%3C0227:CTAFEO\%3E2.0.CO;2
4. Bagchi R, Miah MA, Islam MA, Bithi SA, and Shamsuzzoha M. (2019). Assessment on climate change adaptation: a study on coastal area of Khulna district in Bangladesh, Aust. J. Eng. Innov. Technol., 1(6), 14-20. https://doi.org/10.34104/ajeit.019.14020

5. BBS. (2012). Statistical Yearbook of Bangladesh, Bangladesh Bureau of Statistics, Ministry of Planning, Government of the People's Republic of Bangladesh.

6. Wisner B., Blaikie, P., Cannon, T., Davis, I., \&, (2014). At risk: natural hazards, people's vulnerability and disasters. Routledge. ISBN/ISSN9780415252164, p 471.

https://www.preventionweb.net/publications/vi ew/670

7. CEGIS. (2009). Report on Cyclone Shelter Information for Management of Tsunami and Cyclone Preparedness. Comprehensive Disaster Management Programme (CDMP)

8. Choudhury, J. R. (1994). Cyclone shelter and its multipurpose use. In Proceedings of the IDNDR Aichi/Nagoya International Conference (pp. 1-4).

9. Nasreen, M., Hossain, K. M., \& Azad, M. A. K. (2013). Climate Change and Livelihood in Bangladesh: Experiences of people living in coastal regions. Proce. of Int. Con. of Building Resilience, 1-25.

10. Uddin, M. S., Ahmad, M. M., \& Warnitchai, P. (2018). Surge dynamics of disaster displaced populations in temporary urban shelters: future challenges and management issues. Natural Hazards, 94(1), 201-225.

Citation: Rasheduzzaman M, Uddin A, Shamsuzzoha M., and Rahman MA. (2020). Analysis of cyclone shelter patterns to build a better shelter management: a case study of Bangladesh southern region, Asian J. Soc. Sci. Leg. Stud., 2(3), 47-55. https://doi.org/10.34104/ajssls.020.047055 @ 